\title{
IMPLICATION OF ENTERPRISE AND ENTREPRENEURSHIP EDUCATION ON PRIMARY SCHOOL
}

\author{
Siska MAYA \\ Faculty of Science and Social Education, Indraprasta PGRI University, Indonesia \\ may3110@yahoo.com
}

\begin{abstract}
The formation of entrepreneurship spirit is influenced by external factors from surrounding environment such as family, physical, social economy and other environments. Contextual factor like entrepreneurship education, entrepreneurship experience, academic and social support, also business environment are predicted to have influence to entrepreneurship motivation. Building entrepreneurship character in children is more about how to assemble the nature and characteristic which independent, responsible with the help of entrepreneurship education theoretically and practically, and also real example, due to the time long process of characteristic construction. The research method that is used is qualitative using descriptive and investigation method. The purpose of the research is to know how is the entrepreneurship learning in school, to analyze the obstacle and support in developing the entrepreneurship learning and also to know is there any its influence towards forming the student's entrepreneurship characteristic. The project system which is held by the school is very helpful for the student to become more convenient in teaching and learning process. Because project system carried out not only in the class but also exploration and survey outside the class. The output from Enterprise Education are creative and innovative meanwhile from Entreprenuership Education are knowledge in the business world.
\end{abstract}

Keyword : Entrepreneur, Entrepreneurship Education, Primary School

\section{BACKGROUND}

Government wants to increase the number of entrepreneurs. The amount of unemployment and poverty in Indonesia decrease with the increasing of entrepreneurs. If the entrepreneurship is strong, it will create fair economic growth so that economy divergence will be grinded gradually. Based on Ministry of Cooperatives Small and Medium Enterprises data, Anak Agung Gede Ngurah Puspayoga the Minister of Cooperatives Small and Medium Enterprisessaid that the amount of entrepreneurs in Indonesia increase from $1,67 \%$ to $3,10 \%$ from the total of Indonesia's population which is 225 million people. But this number is still lower than the quantity of entrepreneurs in our neighboring countries like Malaysia $6 \%$, Singapore $7 \%$, and Thailand $5 \%$ from each their population. (Pikiran Rakyat, 2017) "Entrepreneurship education has been taught in several public and private universities as one of the curriculum. Application of this course and the creation of business center incubator in several universities are expected to be able to produce many graduates which have entrepreneur motivation."

According to Priyanto that quoted by Doddy Adhimursandi (2016) the formation of entrepreneurship spirit is influenced by external factors from surrounding environment such as family, physical, social economy and other environments. Contextual factor like entrepreneurship education, entrepreneurship experience, academic and social support, also business environment are predicted to have influence to entrepreneurship motivation (Grubuz \& Aykol, 2008). Several research show result that education and entrepreneurship education debriefing since early age are able to develop someone's potency to become an entrepreneur (Kourilsky \& Walstad, 1998: Gerry et. al., 2009). In addition, Wibowo's (2011) research state that learning entrepreneurship at school have the highest influence in student's interest for entrepreneurship.
Armaini Rahman (2015) explain that entrepreneurship education is able to be taught to children in early age with forming the entrepreneurship character. A child character is built through what they hear, see and feel. Hearing and sight are the entrance of a lesson before forge into a child conscience. Through all sense that owned by human being, will emerge a strong lesson which is related with what the senses obtained. If a child accustom with entrepreneurship since early age, this character will show when he/she grows up.

Entrepreneurship education for children are forming the entrepreneurship character. Because in entrepreneurship education not only teach children about how to do business. More than that children are train to have strong spirit and character. Children are taught to know themselves, how to handle emotion and stress, time management, communicative ad flexible in various situation, also able to choose and make decision. Building entrepreneurship character in children is more about how to assemble the nature and characteristic which independent, responsible with the help of entrepreneurship education theoretically and practically, and also real example, due to the time long process of characteristic construction.

The purpose of the research is to know how is the entrepreneurship learning in school, to analyze the obstacle and support in developing the entrepreneurship learning and also to know is there any its influence towards forming the student's entrepreneurship characteristic.

\section{Foundation of The Theory \\ 1. Learning Method}

Educators in this state are teachers which one of success keys in the implementation of a good curriculum. Of course schools have their own curriculum. It is an entrepreneurship teacher obligation in developing his/ 
her knowledge especially in the flied of entrepreneurship. It is have to be done therefore it will enrich the teaching materials. This is also said by Katherine Fulgence (2015), the need for teacher to enhance their capacity for the developing the characteristics of entrepreneurship.

Entrepreneurship teaching specifically for primary student is able to dig by intrapersonal. Intrapersonal intelligence in Azwar according to Gardner and Hatch (2006) is someone ability to access his/her own feelings, and the ability to differentiate those feelings also use them for led his/her behaviors, the knowledge of someone's power, weakness, wishes, and intelligence. This Intelligence is needed for entrepreneur candidate in order that they are more sensitive towards their environment.

Marty Mattare (2007) has the same opinion that entrepreneurship students have to possess a good understanding regarding of themselves, tools to correct themselves, a strong self-efficacy, and the ability to overcome constructive failure and try again. Teaching students to know themselves and also the habit to rectify their failure and dare to try again.

According to Stern in Syukur Ghazali (2010) there are four type of basic learning strategy:

1. Active learning strategy (defining the purpose or sub-purpose, recognizing learning steps and actively participate in the learning process. These can be applied in primary education through bazar activity which routinely done at school.)

2. Explicit learning strategy (present linguistic aspect from language target, conscious learning, language practice, memorizing and monitoring progress)

3. Social learning strategy (endeavor to communicate with target language speakerand its community, developing communication strategies, involve in situations which using authentic language)

4. Affective strategy (Doing tasks with positive attitude, develop the energy which needed to handle the frustration in learning and overcome the emotional and motivational problems.

\section{Entrepreneurship Spirit}

Forming entrepreneurship spirit is able to be designed in the form of habit. Habits which applied in everyday activitiesgive a huge effect. Saiman Leonardus (2014) said that there are 12 principals in entrepreneurship, there are:

a. Do not be afraid to fail. Starting or running a business must have dare to try character. This has to be accompanied with other entrepreneurship principals, which is sharpness in analyzing.

b. Energetically. Advice from Harvey McKey, the greatest appreciation for entrepreneur is not the objective but more to the process or the journey.

c. Creative and innovative. Both of the characteristic are principal fundamental for an entrepreneur. An entrepreneur should not quit to be creative and innovative in all thing. d. Measures with complete calculation in taking risk. Risk will always there wherever we are.

e. Patient, tenacious, and diligent. Other principals that not less important in trying are patient and tenacious. Entrepreneur emotional intelligence is the ability of latent emotional which influenced the transformation leadership orientation. Charismatic-inspirational behavior, entrepreneur show their skill for managing their emotion because it has influence towards growth. (Ronit Yitshaki dan Ronit Yitshaki,2012)

f. Must be optimistic. Optimist is business capital which is important for entrepreneur, because the word of optimistic is a principal that able to motivate our consciousness, so whatever our business that we do must be full of optimistic or believe that our business can be success.

g. Ambitious. This principal should be owned by entrepreneurs for any kind of business that they have.

h. Never give up/ don not despair. This principal is a part that have to be done anytime.

i. Keen to the market or able to read market opportunity. Keen to the market principal or able to read market opportunity principal is absolute principle that must be done by entrepreneurs at local, regional and international level.

j. Business with ethics standards. Principal that every entrepreneur must hold well ethics standard which generally applicable.

k. Independent. Independent principal have to be a guide in entrepreneurship. Being independent in many things is an important key so we able to avoid dependency towards parties that concerned to our business.

I. 1. Honesty. Pythagoras said that honesty is currencies that sold everywhere.

m.m. Care about the environment. An entrepreneur must have concern for his/her environment so it is necessary to participate in preserving his/her business environment

\section{Entrepreneurship Education.}

The important to make an investment.

Gerba, D.T. (2012) entrepreneurship education is a conscious effort byindividuals to increase knowledge about entrepreneurship. This explain that entrepreneurship awareness needs to be increased with the knowledge about entrepreneurship itself. Entrepreneur knowledge is able to acquire from the information that we can get from other entrepreneur. Entrepreneurship education which given in formal education usually to know the theory about what aspects that should be fulfill for being an entrepreneur. The application of entrepreneurship education in formal or informal education its own concept to teach the entrepreneurship culture. This also said by Kurniawan, R. (2013), entrepreneurshipeducation is a discipline that studies on values, skills, and behavior in the face of life's challenges to pursue opportunities with a wide range of risks that may beencountered. Entrepreneurshipeducation 
is one of knowledge discipline that teach about value, skill and behavior in facing life challenges for pursuing the opportunity with every risk that maybe encountered.

Entrepreneurship continuous to be develop by the government through micro, small, and medium business. Because it made a positive impact towards economy development. In line with the opinion of Linan \& Rodriguct (2004)that entrepreneurship had a role as one of important instrument in economy development and economy structural adjustment nowadays.

Entrepreneurship education is very important to be given attention and develop. This have a purpose that the students are able to get an optimal entrepreneurship education. Inserting positive attitude is able to be done since early age. This is to avoid behaviors that are not supposed to (cheat) both to the customer and partner. Entrepreneurship education is expected to give moral outcome for every student characteristic. Someone's personal moral behavior is very important in workplace, this is a sign for motivation and individual attitude (Singh, Bhandarker, Rai \& Jain, 2011)

\section{METHOD}

The research method that is used is qualitative using descriptive and investigation method. The research approach are Psychology and sociology approach using constructivism learning theory. The research subjects are the parties that involve and competent in entrepreneurship education in the school.

Data source: Headmaster, teachers, parents, and students. Sampling technique that is used is purposive sampling because it intended to the person that assumed is the most understand with the entrepreneurship education process in the school.

\section{RESULTS AND DISCUSSION}

$\mathrm{XYZ}$ school is a primary school that is from grade 1 until 6 with learning method that using different themes every week. Based on the interview in the school, TechnonaturaSchool using project as their learning method. The project are engineering, social and science projects. The projects switch is done every week. For example if this week theme is social project that means next week is entrepreneuer project. Entrepreneueris made as a part in the curriculum of the school. With the purpose that the students will have entrepreneuership spirit. Saiman Leonardus (2014) said that there are 12 principals that have entrepreneuership spirit:

1. Do not afraid to fail

In this school the students are taught how failure is a usual thing that often to happen. So every time students faced failure, they have to try something. The failure is the lesson which is learned. As an example, in school A there is a Ramadan Bazar for four days. For four day the students are able to sell food that can be switch every day. The foods or drinks switching happen because the products which offered are not interesting. Based on the interview with one of the student's parent, it said that on the first day her son/daughter sell noodle satay. Because it was not interesting, the student did product evaluation. After the evaluation he/she switches the product with more interesting product.

2. Full of spirit

The students which follow the entrepreneuer activity must not lose their spirit. Because the activity done with their own effort. This spirit also spread by their mentor. That is why every group have their own mentor for monitoring.

3. Creative and innovative.

The stimulus that is done by the mentors towards the students is that there is right or wrong in their idea or action. This makes the students enthusiast in finding ideas so the creativity created. The innovation became more various. Ken robin (2015) in his book said that supporting school system with flexibilities and innovation is really needed. Titus (2014) in his research said that creativity is really needed, the creativity from the teacher as well as the students. Teacher's creativity certainly in learning process which made it more applied. While student's creativity can be encourage by looking for solution from the problems that exist. Creativity is a machine while motivation and hard work is the gasoline in the road toward success (Ivana Dudova dan Jakub Ciba, 2015). Creative and innovation are trained in Technotura school with robot assembling which students learn in engineering project.

4. Sensitive towards the market or able to read market's opportunities

In school A, student's ability is sharpen for sensitive towards market's demand. This is started with the students having field survey to know the newest market's condition. In Technotura School, the students also trained to become more sensitive against the market or environments. The students are asked to observe the field that is traditional market and supermarket to learn how to analyze what product that popular atthe market.

5. Independent

Independent characteristic that is usually done by students made them able to solve their own problem. Certainly this habit is supported by mentor with giving them their trust in finding the solution of every problem. Based on the survey and interview to the Technonatura's school students, obtained that 16 from $20(80 \%)$ students is independent which can be seen from they did house chores by their own like washing the dishes after meal. $20(100 \%)$ students always get up early and do dawn prayer (sholatsubuh). The support from family is very important to train students' independent. Giving trust to children to clean the house, bedroom, and bathroom are showing support for children independent. 15 from 20 students that get interview did not like to ask favor from housekeeper to finish the house chores. 
6. Honesty.

Honesty which embed to the students can be seen in evaluation every period. The students were given a chance to analyze what happen in the field freely. Speak freely is also trained in Tecnonatura School by doing discussion and team work in class. 20 students which are interviewed like to do team work and also to hear other students' opinion.

Entrepreneuership education is able to be one of school subject. However entrepreneuership education will more effective if it integrated with other subject. Endang Mulyani (2011) said that entrepreneuership education can integrated with other school subject.

Nowadays Indonesia should have implemented to increase the education quality. The bad performance of Indonesia's education not only lack of human resources, bad incentives structure, and management. But also politic and power problems (Andrew Rosser, 2018)

Primary school applied enterprise and entreprenuereducation concept. Brian Jones dan Norma Iredale (2010) said entrepreneurship education main focus are:

a. How to start a business which consist of the keys to start a business. A Simple Marketing Mix theory is introduced in school A. There are $4 \mathrm{p}$ : product, price, place and promotion.

b. How to plan and launch a new business. Students in school A is taught how to plan a business. The application is at school bazar. Every student start from level 1 can do preparation in a new business that will be held in the school bazar. It begin from the how much capital must be provided until how to predict the sales profit.

c. How to grow and manage business. Managing a business certainly will be a good learning. Students usually do observation in the field to learn nowadays condition in business. After observation the students have to write report about everything that happen or what they learn in the field. After that the student present their report in the class by doing a presentation.

d. How to increase competence and behavior that needed to run a business. According to Taina Jarvi (2015), learning in small enterprise is continuing process related between theory and applied process. The learning core in small enterprise are reflection of action, it will have connection with the development of entrepreneuership competency. Students in this school also went to the small business to do observation. Their teacher said they do it to see the real form of entrepreneuership. For example what kind of product that consumer preferred to, what kind of product that qualified and other knowledge.

e. Spreading the entreprenuership skill and knowledge in business context

f. The use of knowledge and skills which are needed to start a business

g. Entreprenuership
The main purpose of enterprise education is to strengthen the students with competence and skill that help the students to overcome and adapt with changes in work market condition and allow them to have their own future (Brian Jones dan Norma Iredale, 2014). According to Brian Jones dan Norma Iredale (2010) the main focus of enterprise education are:

a. Pedagogy active business learning education

b. Knowledge that needed for effective function as citizen, consumer, employee or businessman in flexible economy market.

c. Individual skill development, attitude, and attribute to be used in various context

d. People as an active individual in society, home, workplace or as a businessman

e. The use of skill, attitude, and attribute actively through life and

f. How a business, especially a small one work

Entreprenuership education include using traditional approach of Jones dan Iredale in Brian Jones dan Norma Iredale (2010) for learning and studying business idea, business planning and the process of the creation of new business. On the contrary, enterpriseeducation take more creative and innovative learning approach which use experiential action. Enterpriseeducation scope and practice is wider than entreprenuership education which are too focusing in how to start a business. Ulla Hytti dan Colm O'Gorman (2004) said that enterpriseeducation in primary school is to increase students' enterprise skill and to create more understanding about working world through community connection.

\section{CONCLUSION}

Increasing entrepreneurship spirit or entreprenuer would be more effective if it is done in formal education. Enterprise and entreprenuer education can be applied from primary school, certainly adapted with the students' condition. Both of this approach are very suitable practiced starting primary school. Teknonatura School does its daily activities in the school to develop entreprenuer attitude and spirit. The project system which is held by the school is very helpful for the student to become more convenient in teaching and learning process. Because project system carried out not only in the class but also exploration and survey outside the class. The output from Enterprise Education are creative and innovative meanwhile from Entreprenuership Education are knowledge in the business world. Gary Packham, et.al (2010) said that Enterprise Education has positive impact toward entreprenuership spirit.

\section{REFERENCE}

Adhimursandi, Doddy. 2016. Faktor-Faktor Yang Mempengaruhi Niat Kewirausahaan. Kinerja : Jurnal Ekonomi dan Manajemen, Volume 13, (1). Universitas Muliawarman. 
Andrew Rosser.(2018). Beyond Access: Making Indonesia's Education System Work. https://www. lowyinstitute.org/publications/beyond-accessmaking-indonesia-s-education-system-work diakses 20 Juni 2018 1:40

Azwar. 2006. Pengantar Psikologi Inteligensi. Yogyakarta: Pustaka Pelajar

Dudova, I., \& Ciba, J. (2015). Application of Creativity In The Educational Process. CBU International Conference on Innovation, Technology Transfer and Education, 95-101.

Gerba. D. T. (2012). Impact of entrepreneurship education on entrepreneurial intentions of business and engineering students in Ethiopia. African Journal of Economic and Management Studies.Vol. 3 No. 2.pp. 258-277.

Gerry. C, Susana. C, \& Nogueira, F. 2008. Tracking Student Entrepreneurial Potential: Personal Attributes and the Propensity for Business StartUps after Graduation in a Portuguese University. International Research Journal Problems and Perspectives in Management, 6 (4). Page. 45-53.

Ghazali Syukur (2010). Pembelajaran Keterampilan Berbahasa. PT.Refika Aditama

Grubuz, G., \& Aykol, S. 2008. Entrepreneurial Intensions of Young Educated Public in Turkey. Jurnal of Global Strategic Management, 4 (1), 47-56.

Hytti, U., \& O'Gorman, C. (2004). What is "enterprise education"? An analysis of the objectives and methods of enterprise education programmes in four European countries. Education \& Training. Emerald Group Publising Limited , 46 (1), 11-23.

Jarvi, T. (2015). Production of entrepreneurship in small business activities of students. Journal of Small Business and Enterprise Development, 22 (1), 180-191.

J, S. (2016). Educational Effective and Ineffectiveness. Springer Science+Business Media Dordrecht.

Jones, B., \& Iredale, N. (2010). Enterprise education as pedagogy. Education + Training, 52 (1), 7-19.

Jones, B., \& Iredale, N. (2014). enterprise and entrepreneurship education:towards a comparative analysis. Journal of enterprising Communities: People and Places in the Global Economy. Emerald Group Publishing Limited, 8 (1), 34-50.

Katherine Fulgence, (2015). Assessing the status of entrepreneurship education courses in higher learning institutions, Emerald Group Publishing Limited Vol. 57 No. 2 pp. 239-258

Kourilsky, M.L. \& Walstad, W.B. 1998. Entrepreneurship and Female Youth : A Curricular Perspective, in
Sexton, D.L. \& Sanlow, R.W. (Eds). Page 193-213. Chicago : Upstart Publishing.

Kurniawan, R. (2013). Pengaruh Penerapan Model Pembelajaran Teaching Factory 6 Langkah (TF6M) dan Prestasi Belajar kewirausahaan Terhadap Minat Wirausaha. Jurnal Pendidikan Teknologi Kejuruan.Vol. 10 No. 1.pp. 57-66.

Marty Mattare (2007). Use of Self 101: The Case for Teaching Personal Development in the Entrepreneurship Curriculum. NEW ENGLAND JOURNAL OF ENTREPRENEURSHIP. P 17-28

Mulyani, E. (2011). Model Pendidikan Kewirausahaan di Pendidikan Dasar dan Menengah. Jurnal Ekonomi \& Pendidikan, 8 (1).

Packham, G., \& all, e. (2010). Attitudes towards entrepreneurship education: a comparative analysis. Education + Traning Emerald Group Publishing Limited, 52 (8/9), 568-586.

Pikiran Rakyat.2017. Rasio Wirausaha Indonesia Naik Jadi 3,1\%. http:/www.pikiran-rakyat.com/ ekonomi/2017/03/11/rasio-wirausaha-indonesianaik-jadi-31-395913. Diakses 28 April 2017.

Rahman, Armaini. 2015. Pembelajaran Penumbuhan Jiwa Kewirausahaan Pada Anak Usia Dini Apakah Dibutuhkan?. https://armainirahman1977. wordpress.com/2015/03/12/pembelajaranpenumbuhan-jiwa kewirausahaan-pada-anak-usiadini-apakah-dibutuhkan/Diakses 29 April 2017.

Robinson, K. AndAronica, L. (2015). Creative School, The Grassroots Revolution that's Transform Education, Viking. https://www.theguardian.com/books/2015/ apr/23/creative-schools-revolutionising-educationfrom-the-ground-up-ken-robinson-lou-aronicareview

Ronit Yitshaki dan Ariel. How Do Entrepreneurs' Emotional Intelligence and Transformational Leadership Orientation Impact New Ventures' Growth?.Journal of Small Business and Entrepreneurship 25.3 (2012): pp. 357-374

Saiman Leonardus (2014) Kewirausahaan : Teori, Praktik dan Kasus-kasus. Salemba Empat. Jakarta

Singh, P., Bhandarker, A., Rai, S. \& Jain, A.K. (2011). Relationship between values and workplace: an exploratory analysis. Facilities, Vol. 29, no. 11/12, 499-520.

SUCIU, T. (2014). The Importance of Creativity in Education. Bulletin of the Transilvania University of Brasov , 7 (2), 151-158.

Wibowo, M. 2011. Pembelajaran Kewirausahaan Dan Minat Wirausaha Lulusan SMK. Eksplanasi, 6(2), 109-122. 